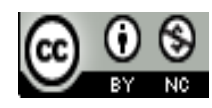

JurnalTerapanManajemendan Bisnis is licensed under

A Creative Commons Attribution-NonCommercial 4.0 International License.

\title{
A COMPARATIVE ANALYSIS OF THE LEVEL OF BANKING SOCIAL REPORTS DISCLOSURE IN INDONESIA (ISLAMIC SOCIAL REPORTING AND CORPORATE SOCIAL RESPONSIBILITY APPROACH)
}

\author{
Moh. Bahrudin'1), Ahmad Habibi'2), Muhammad Iqbal ${ }^{3)}$ \\ 1) UIN Raden Intan Lampung, Lampung, Indonesia \\ E-mail: bahrudin@radenintan.ac.id \\ 2) UIN Raden Intan Lampung, Lampung, Indonesia \\ E-mail: habibi@radenintan.ac.id \\ 3) UIN Raden Intan Lampung, Lampung, Indonesia \\ E-mail: iqbalfebi@radenintan.ac.id
}

\begin{abstract}
This study aims to analyze the differences between conventional social reporting concepts of Corporate Social Responsibility (CSR) based on previous studies with the concept of Islamic Social Reporting (ISR) disclosure both in Islamic banks and conventional banks. The populations of this study are Islamic commercial banks and conventional banks. This study took 8 banks consisted of 4 Islamic banks and 4 conventional banks. The Independent Sample t-Test was used to analyze the data. The results of the study show that the use of the ISR index and CSR between sharia and conventional banks are different from each other in term of the companies'social report disclosure.
\end{abstract}

Keywords: Conventional Banks, CSR, Islamic Banks, ISR

\section{Introduction}

Information is a fundamental need for investors and potential investors in decision making. The existence of complete, accurate, and timely information allows them to make rational decisions so that the results obtained are most likely to be as expected. According to the 1995 capital market law, material information or facts are important or relevant information or facts regarding events, incidents, or facts that can affect the price of securities on the stock exchange, and decisions of investors, prospective investors or other parties with an interest in the information or facts.

One of the information that is often asked to be disclosed by companies today is information regarding corporate social responsibility (CSR). Guthrie and Mathews as quoted by Sembiring stated that corporate social responsibility itself can be described as the availability of financial and non-financial information related to organizational interactions with the physical environment and social environment, which can be made in a company's annual report or separate social report (Sembiring, 2005). 
Utama states that CSR in Indonesia is related to the increasingly severe damage to the environment that occurs in Indonesia and the world, ranging from deforestation, air, and water pollution, to climate change (Utama, 2017). According to Daniri, CSR is still considered a trivial thing and is run half-heartedly by the company (Daniri, 2017). CSR is carried out only to get public attention. Utamastates that currently, the level of CSR reporting and disclosure in Indonesia is still relatively low because until now there has been no agreement on CSR reporting standards that can be used as a reference for companies in preparing CSR reports, as a result, the report disclosure activities of CSR by the companies are very diverse.

The company's financial statements are one of the indicators to assess the performance of the company itself. In addition, financial statements are a source of information for other parties outside the company's management. The annual report of a company is a source of information for investors as a basis for consideration in making investment decisions in the capital market and also as a means of accountability management or resources entrusted to it.

The financial statements provide insight into the current status of the company and develop future policies and strategies (Lyn M., 2008). Financial statements are also one of the most important media in the business decision-making process. The existence of financial statements is expected to provide information about the results of financial operations and various factors that cause changes in financial position (Hanafi \& Halim, 2000). Financial statements are a tool for reporting company activities that include investment activities and operational funding as well as to evaluate the success of the company's strategy to achieve the objectives to be achieved.

Financial report analysis essentially aims to provide a more feasible and systematic basis for predicting what might happen in the future, considering the data presented by financial statements describe what happened (Prastowo, 1995).

With regard to the analysis of financial statements that require completeness of company information for social disclosure. This information depends on the level of completeness of disclosure from the financial statements of the company concerned. This disclosure is a very influential factor in achieving companies' efficiency and is a means of public accountability.

The report of the level of company disclosures related to social issues for the community can describe the company itself. Financial statements that are made to meet the objectives of accountability and transparency, not only for Muslim decision-makers but also to help the companies that belong to the sharia category to fulfill their obligation to God and society. Moreover, companies that belong to the sharia category are companies that the people aim to invest in accordance with the principles they believe in, at least this will add a separate motivation for investors to invest.

Corporate Social Responsibility is one of the information that is often asked to be disclosed in corporate reporting. The term Corporate Social Responsibility has become an important issue related to the issue of environmental impacts on sustainable development. This emerged as a reaction from many parties to the damage to the environment both physically, psychologically, and socially, as an impact of the management of production resources from the company (Purwanto, 2010).

In practice, the company's social responsibility actions are not only in the form of being generous temporally but conceptually far more than just generosity. So that with regard to CSR issues that surfaced, it needs to be explored further, especially in the scope of companies in the large category of finance in both Islamic banks and conventional commercial banks. 
There are many previous studies regarding the analysis of factors that influence the level of corporate CSR disclosure. On the other hand, very few still use the ISR framework in proving the factors that influence the level of disclosure of the ISR. The framework of the performance reporting of social responsibility in accordance with Islamic principles (Islamic Social Reporting) can show the company significantly in making reporting of social responsibility. Likewise, the factors that influence the level of the corporate social disclosure are viewed from the side of Corporate Social Responsibility, which only uses positive legal aspects in the disclosure concept.

In the research involving various elements in financial statements especially those related to the level of disclosure by financial corporations in the form of banks, both conventional commercial banks, and Islamic banks. Company samples were taken based on the sharia category because the company in this category is one of the alternativesfor the society to make an investment where the sharia principle is the main foundation. This research tries to find out whether there are differences in social reporting in both conventional commercial banks and sharia commercial banks in terms of the character of Islamic Social Reporting and Corporate Social Responsibility.

The index of Islamic Social Reporting (ISR)is a continuation of the disclosure of Corporate Social Responsibility (CSR) based on sharia principles. Based on the description of the comparison between the two indices, the researcher took the title "A Comparative Analysis of the Level of Banking Social Reports Disclosure in Indonesia".

\section{Theoretical Basis}

Disclosure is one of the information that is often asked to be stated in company reporting. The term Corporate Social Responsibility has become an important issue related to the issue of environmental impacts on sustainable development. This emerged as a reaction from many parties toward the environmental damage both physically, psychologically, and socially, as an impact of the management of production resources from the company. In practice, the company's social responsibility actions are not only in the form of being generous temporally but conceptually far more than just generosity.

This CSR issue emerges along with the development of a company that should be carried out based on their responsibility toward the social environment. There needs to be a study that is more relevant to this reporting issue. The characteristics of companies'reporting have rarely used the mechanism of ethical principles in its application. Corporate Social Responsibility can be linked to ethical issues; one of them is the concept of Islamic Social Reporting which puts the foundation of religiosity as an ethical standard in it.

Islamic Social Reporting is one of the concepts of financial reporting based on the basis of Islam as a starting point. The size of the company may potentially increase conflict between company management and shareholders (Inchausti, 1997). To reduce the turmoil of the conflict, large companies need to report socialresponsibility information. With the addition of information relating to social responsibility, the index of Islamic Social Reporting, there will be clear financial transparency from management to shareholders, especially for Muslim shareholders.

\section{Previous Research}

Haniffa (2002) states that the conventional social reporting framework only considers material and moral aspects so that there is an imbalance in the disclosure of accounting information related to corporate social responsibility, which depends on groups that have the greatest strength. Whereas in sharia principles, it must include material, moral,and spiritual 
aspects that placea relationship between humans and God, humans, and humans, and humans with nature. Therefore, we need a reporting framework based on sharia principles in building Islamic Social Reporting. The report was made to meet the objectives of accountability and transparency, not only for decision makers from among Muslims but also to help companies, especially companies in the category of sharia to fulfill their obligations to God and society.

Corporate disclosures involve costs incurred for disclosure (Cooke, 1992). Companiesoften disclose their information that is more than required in applicable regulations. When voluntary additional disclosures are made, it can be assumed that the resulting profits exceed the costs incurred for voluntary disclosure (Cooke, 2002; Evans, 2003). One way to provide voluntary disclosure in Islam is by utilizing the Islamic Social Reporting (ISR).

Research on voluntary disclosure by testing the factors that influence the magnitude of the disclosure has been done using a sample of companies in different countries. These studies employed samples of public companies in Western Europe by Adams et al (1998), companies in New Zealand (Hackston \& Milne, 1998), companies in Malaysia by Haniffa \& Cooke (2005), companies in Saudi Arabia by Alsaeed (2006), and companies in Qatar by Hussain \& Hammami (2009). By using the ISR framework that was created by Othman et al. (2009), this study will try to prove whether the level of ISR disclosure carried out by Islamic and conventional banks is different if seen from Islamic Social Reporting and Corporate Social Responsibility. Thus it can provide an understanding of whether there are differences in the level of Islamic bank social reporting and conventional commercial banks in terms of conventional Corporate Social Responsibility (CSR) and in terms of Islamic Social Reporting (ISR).

\section{Research Hypotheses}

Based on this description, the hypotheses in this study are:

Ha1: There is a significant difference in the level of social disclosure reporting (Islamic Social Reporting) in Islamic Banking and Conventional Banking.

Ha1: There is a significant difference in the level of social disclosure reporting (Corporate Social Responsibility) in Islamic Banking and Conventional Banking.

Ha1: There is a significant difference in the level of Islamic Social Reportingon Islamic Banking and reporting on the level of Corporate Social Responsibility in Conventional Banking

\section{Methodology}

This study is a literary study by reviewing various written sources and using secondary data management, while the nature of this research is comparative, namely comparing the level of disclosure of Islamic social reporting and Corporate Social Responsibility in Sharia Banking and Conventional Banking by using independent sample ttest.

The populations of this study were Islamic commercial banks and conventional commercial banks. The sampling method used was purposive sampling with several criteria including:

a. Islamic and Conventional banking which performs its function as a commercial bank that reports its financial statements.

b. Using rupiah as a company reporting currency unit. 
c. Has a positive pre-tax profit value.

d. Total assets between 1-100 Trillion rupiahs.

The sample in this study was Bank Muamalat Indonesia, Bank Syariah Mandiri, BRI Syariah, and BNI Syariah. Whereas Conventional Commercial banks were Bank Negara Indonesia, Bank Central Asia, Bank Mandiri, and Bank Rakyat Indonesia. The research began in 2011 to 2015.

This study employed an unweighted disclosure index, which sees the presence or absence of disclosure information in annual reports and other company reports. So, each disclosure had the same weight. In other words, whatwas measured was the level of completeness of information disclosure. Each disclosure hadascore of 1 or zero (0). If the disclosure was contained in the company's data source, then 1 score would be given and vice versa, if there was none, then no score would be given. The scores of each company would be accumulated based on the theme and overall aspects. The score to be included in the ISR and CSR variables was the overall score. This study calculated the amount of disclosure of the type of ISR disclosure contained in company data. This study used the index of Islamic Social Reporting and Corporate Social Responsibility proposed by Othman, Thani, \& Ghani (2009) with some adjustments.

The data analysis used in the research model was the comparative analysis method using Independent Sample t-Test aimed to find out whether there are differences between the variables used in the ISR index and CSR from both Islamic banking and conventional banking.

\section{Research Results and Discussion}

Normality test was conducted to determine the normality of the data so that the residual value will be distributed normally and independently. One way to test the normality of the data is the Kolmogorov-Smirnov test.

Table 1 Kolmogorov-Smirnov One-Sample Test

\begin{tabular}{lrr}
\hline Test & ISR Index & \multicolumn{1}{c}{ CSR Index } \\
\hline Kolmogorov-Smirnov Z & 0.518 & 1,046 \\
Asymp. Sig. (2-tailed) & 0.951 & .224 \\
\hline
\end{tabular}

The normally distributed research datacould be tested using comparative analysis of independent sample t-test to find out the comparison between both the ISR index and CSR in Islamic banks and conventional commercial banks.

Table 2 Research Results

\begin{tabular}{ccccc}
\hline Variable & $\begin{array}{c}\text { Conventional } \\
\text { Banks }\end{array}$ & Sharia Banks & t-observed & Sig \\
\hline ISR Index & 0.643 & 0.719 & -7.139 & 0.000 \\
CSR Index & 0.758 & 0.640 & 12.623 & 0.000 \\
ISR vsCSR & 0.758 & 0.719 & 3.102 & 0.003 \\
\hline
\end{tabular}

Facts on the field showed that the level of disclosure index between Islamic Social Reporting that there were significant differences between sharia banks and conventional banks. The disclosure characteristics indication can be seen from each disclosure item. The difference in disclosure items was only found in items with financial and investment themes 
and Corporate Governance. This shows that sharia commercial banks are better at disclosingIslamic Social Reporting information index to the public than conventional banks.

On the contrary, there was a significant difference in the disclosure of the social report between Islamic and conventional banksusing Corporate Social Responsibility. The items of social reports disclosure of financial statements at conventional commercial banks are more revealed than sharia banks. This shows that conventional commercial banks are better at disclosing their social information to the public than sharia banks.

\section{Conclusion}

Based on the results of the study, the conclusions that researchers could draw are as follows:

1. Based on the results of statistical tests, it can be concluded that there is significant difference between the level of social report disclosure of sharia banking and conventional commercial banks using the index of Islamic Social Reporting (ISR). This means that the use of the ISR index between sharia and conventional banks is different from each other to the level of disclosure of the company social reports.

2. There is a difference in the use of Corporate Social Responsibility index between sharia and conventional banking in terms of social disclosure. This means that the use of CSR index between sharia and conventional banks is different from each other on the level of disclosure of corporate social reports.

3. Based on the results of statistical tests, it can be concluded that there is are significant differences in the disclosure level of CSR of conventional commercial banks and ISR Disclosure level in sharia banks. This means that the use of the indices between the ISR of the sharia banking and the CSR of the conventional banking are different from each other on the companysocial reports disclosure level.

This study only identifies the level of disclosure of corporate social reports by using two disclosure items, namely the Islamic Social Reporting index and the Corporate Social Responsibility index in the annual financial statements both in sharia banking and conventional banking. This study does not examine the effect of social responsibility reports on market performance, in this case, the investor's reaction to the information.Besides, the researchers only examined one reporting media, namely financial statements, and annual financial statement, so that a more detailed information on social responsibility disclosures could not be obtained. There is subjectivity in determining the disclosure index since there is no standard provision that can be used as a reference standard, so the index determination for the same GRI indicator could produce different results between researchers.

A suggestion for further research is to test the application of corporate social responsibility and to consider using other reporting media that can be used by companies to make social accountability. Future research is expected to reveal theoretically the company social disclosure so that it can correct the shortcomings of research that has not been revealed.

\section{References}

Abul, Hassan., Salma. (2009). Corporate social responsibility of Islamic financial institutions and businesses Optimizing charity value. Humanomics journal - volume 25 Maret 2009.

Debby, Faras Ayu. (2010). Analisis Pengaruh Jenis Industri, Ukuran Perusahaan, dan profitabilitas terhadap Islamc Social Reporting pada perusahaan yang masuk Jakarta Islamic Index. Proceeding Seminar dan Koloikum Sistem Keuangan Islam III.SBM ITBBandung 14 Agustus 2010. 
Eduardus Tendellin. (2001). Analisis Investasi dan Manajemen Portofolio. Yogyakarta: BPFE Yogyakarta.

Fraser Lyn M. (2008). Memahami laporan Keuangan (alih bahasa priyo darmawan). Jakarta: PT Indeks.

Hartono. (2010). SPSS 16.0. Yogyakarta: Pustaka Pelajar.

Karim, Adiwarman. (2010). Bank Islam Analisis Figh dan Keuangan, Jakarta: Rajawali Press.

Kuncoro, Mudrajad. (2004). Metodekuantitatif: Teori dan aplikasi untuk bisnis dan Ekonomi. Yogyakarta: UPP AMP YKPN.

Mamduh M., Hanafidan., Halim, Abdul. (2000). Analisis Laporan Keuangan. Yogyakarta: UPP AMP YKPN.

Othman., Rohana., Azlan., Md Thani., Erlane K Ghani. (2009). Determinants of Islamic Social Reporting Amog Top Shari'ah-Approved Companies in Bursa Malaysia. Research Journal Of Iternational Studies - Issue 12 Oktober 2009.

Poerwanto. (2010). Corporate Social Responsibility. Yogyakarta: Pustaka Pelajar.

Prastowo, Dwi. (1995). Analisis Laporan Keuangan. Yogyakarta: UPP AMP YKPN.

Sugiyono. (2010). Statistika untuk Penelitian. Bandung: Alvabeta.

Widjaja, Gunawan. (2007). Transplantasi Trust dalam KUH Perdata KUHD dan Undang-undang Pasar Modal Indonesia. Jakarta: Raja Grafindo Persada.

---- (2010). Islamic Social Reporting of Listed Companies in Malaysia. International business and economics research journal - volume 9 April 2010.

Siwar, Chamhuri., TareqHossain. (2008). An analysis of Islamic CSR concept and the opinions of Malaysian managers. Management of Environmental Quality: An International Journalvolume 20 January 2009. 